\title{
Arthropod fauna recorded in flowers of apomictic Taraxacum section Ruderalia
}

\author{
Alois HONĚK ${ }^{1}$, Zdenka MARTINKOVÁ ${ }^{1}$, JiŘi SKUHROVEC ${ }^{1, *}$, Miroslav BARTÁK ${ }^{2}, J_{A N}$ BEZDĚK ${ }^{3}$, PETR BOGUSCH $^{4}$, \\ JiŘi HADRAVA ${ }^{5}$, JIŘí HÁJEK ${ }^{6}$, PEtr JANŠTA ${ }^{5}$, Josef JELÍNEK ${ }^{6}$, JAN KIRSCHNER ${ }^{7}$, VitězsLAv KUBÁŇ ${ }^{6}$, StANo PEKÁR ${ }^{8}$, \\ Pavel PRŮdeK ${ }^{9}$, PAVel ŠTYS $^{5}$ and Jan ŠUMPICH ${ }^{6}$
}

\author{
${ }^{1}$ Crop Research Institute, Drnovska 507, CZ-161 06 Prague 6 - Ruzyně, Czech Republic; e-mails: honek@vurv.cz, \\ martinkova@vurv.cz, jirislavskuhrovec@gmail.com \\ ${ }^{2}$ Czech University of Life Sciences Prague, Faculty of Agrobiology, Food and Natural Resources, Department of Zoology \\ and Fisheries, CZ-165 21 Prague 6 - Suchdol, Czech Republic; e-mail: bartak@af.czu.cz \\ ${ }^{3}$ Mendel University in Brno, Department of Zoology, Fisheries, Hydrobiology and Apiculture, Zemědělská 1, CZ-613 00 Brno, \\ Czech Republic; e-mail: bezdek@mendelu.cz \\ ${ }^{4}$ Department of Biology, Faculty of Science, University of Hradec Králové, Rokitanského 62, CZ-500 03 Hradec Králové, \\ Czech Republic; e-mail: bogusch.petr@gmail.com \\ ${ }^{5}$ Charles University in Prague, Faculty of Science, Department of Zoology, Viničná 7, CZ-128 44 Prague 2, Czech Republic; \\ e-mails: hadravajirka@seznam.cz; janstapetr@gmail.com, pavelstys@gmail.com \\ ${ }^{6}$ Department of Entomology, National museum, Cirkusová 1740, CZ-193 00 Prague 9 - Horní Počernice, Czech Republic; \\ e-mails: jiri_hajek@nm.cz,JJ.Nitidula@seznam.cz,vkuban@nm.cz, jansumpich@seznam.cz \\ ${ }^{7}$ Institute of Botany, Czech Academy of Sciences, CZ-252 43 Průhonice 1, Czech Republic; e-mail: jankirschner@ibot.cas.cz \\ ${ }^{8}$ Department of Botany and Zoology, Faculty of Science, Masaryk University, Kotlářská 2, CZ-611 37 Brno, Czech Republic; \\ e-mail: pekar@sci.muni.cz \\ ${ }^{9}$ Vackova 47, CZ-612 00 Brno, Czech Republic; e-mail: pavelprudek@seznam.cz
}

Key words. Arthropoda, Insecta, plant-herbivore interactions, abundance, annual variation, diurnal variation, host communities, pollen, flower temperature, Taraxacum

\begin{abstract}
Flowers of dicotyledonous plants host communities of arthropod species. We studied the community associated with dandelion (Taraxacum section Ruderalia), a complex of apomictic micro-species abundant in central Europe. Identification of microspecies in the field was impracticable. These plants produce an abundance of flowers that host arthropod communities that are not yet fully documented. We investigated species occurrence, its diurnal and seasonal variation and some of the factors that determine the abundance of the dominant species. Insect and spiders were collected from 2010 to 2012 at a locality in Prague. Whole capitula were harvested at weekly intervals and resident arthropods were identified. Diurnal variation in insect presence and the effect of pollen and microclimate on some of the species were also examined. The insect community ( $>200$ species) consisted mainly of species of Hymenoptera (86 spp.), Coleoptera (56 spp.), Diptera (46 spp.) and Heteroptera (23 spp.). The most abundant were Thysanoptera (2 spp.). Pollen eaters/collectors and nectar feeders dominated over predators and occasional visitors. From April to mid-August, the insect community was dominated by Coleoptera, and later by Diptera and Hymenoptera. Except for Meligethes spp. and species breeding in the capitula, the insects occupied flowers during the daytime when the flowers were open (10-12 $\mathrm{h}$ in spring and only $2-4 \mathrm{~h}$ in late summer). The presence of Meligethes spp. in particular flowers was associated with the presence of pollen; the occurrence of Byturus ochraceus with pollen and flower temperature. Although pollination is not necessary, dandelion plants produce both nectar and pollen. The community of arthropods that visit dandelion flowers is rich despite their being ephemeral. The composition of local faunas of flower visitors, presence of floral rewards and flower microclimate are important factors determining the composition of the flower community.
\end{abstract}

\section{INTRODUCTION}

The genus Taraxacum Wigg. (Asteraceae: Cichorieae: Crepidinae) is comprised of about 62 sections and about 2,800 species native mostly to temperate areas in the
Northern Hemisphere but also common as neophytes in many other regions. It is generally considered to be a complicated example of a genus with coexisting agamospermy and sexuality, as summarized by Kirschner et al. (2003)

\footnotetext{
* Corresponding author; e-mail: jirislavskuhrovec@gmail.com
} 
and Štěpánek \& Kirschner (2012). The problematic features are (i) mutual structural similarity, (ii) agamospermy and common coexistence of agamosperms with sexuals, (iii) hybridity, and (iv) polyploidy. In particular, repeated ancient or recent hybridization events are common in the evolutionary history of the majority of its taxa.

The Taraxacum agamospermy (meiotic diplospory) is associated with a number of features such as a decline in structural features usually accompanying sexual reproduction. In terms of male function, sterility (no or little pollen) and irregular male meiosis resulting in low pollen viability in agamosperms, are recorded. Females may have imperfect capitula or floret opening (or a total reduction in floret display in plants with a reduced tubular ligule, sometimes found in alpine or Arctic dandelions, e.g., T. cucullatum Dahlst.). A variable reduction in nectar production is another trait of this type (see also Richards, 1997; Trávníček et al., 2010). While the shift from sexuality to agamospermy is most frequently an abrupt change following hybridization events, the above structural decline is a result of a long-term mutation process (Richards, 1997).

Our study is focused on agamospermous dandelions of sect. Taraxacum (= sect. Ruderalia Kirschner, H. Oellgaard et Štěpánek), which usually, and for the sake of convenience in what follows, are referred to as T. officinale Wigg. (agg.). It was Nijs et al. (1990) who pointed out that sexual dandelions are confined to the eastern part of the Czech Republic, and we can assume that dandelions in Prague and its vicinity (the source of our material) are exclusively agamospermous. The section Taraxacum consists of about 140 agamospermous microspecies (Trávníček et al., 2010). At a locality (ideally, a mesic grassland, but frequently also a lawn or along road verges) the dandelion population is composed of a few (rarely a single) to many microspecies that differ, in addition to morphological traits, in various adaptive features, including some of the structural features mentioned above. At the locality studied agamospermous microspecies are known to coexist (Hofsten, 1954; Kirschner \& Štěpánek, 1994). Mechanisms of competition and coexistence of these oligoclonal entities are described in Solbrig \& Simpson (1974, 1977).

Flowering is a very conspicuous phenomenon because of a synchronous mass seasonal production of flowers. We refer to dandelion anthodia as "flowers" because a capitulum is a homogeneous unit most likely perceived as a simple flower by insect visitors. Erect peduncles support flowers whose size $(1.5-7 \mathrm{~cm}$ in diameter) varies with soil and climatic conditions and micro-specific affiliation (Hofsten, 1954; Trávníček et al., 2010). Dandelion flowers are large compared with those of most other plants that flower simultaneously at the same sites. Dandelions flower throughout the vegetative season with a peak in spring (AprilMay), when more than $90 \%$ of the annual production of flowers is produced, and another small peak in AugustSeptember (Hofsten, 1954; Sterk \& Luteijn, 1984). The flowering times of individual flowers (periods for which the involucral bracts are spread to expose ligulate florets) vary seasonally (Martinkova et al., 2011). From April to
May, flowers are open for 2.8 days (Martinkova \& Honek, 2008 ), but this may decrease to 1.6 days in summer when conditions are warm and dry (Gray et al., 1973). Flowers open on bright days and close at sunset (Jenniskens et al., 1984). While the presence of pollen differs between microspecies and even among individuals of one micro-species (Trávníček et al., 2010), the presence of nectar is universal (Szabo, 1984; Torres \& Galetto, 2002; Girard et al., 2012).

Season-round presence, high local abundance and large flowers make dandelions attractive to insects. Their flowers are attractive to many insects due to their yellow colour (Láska et al., 1986; Döring et al., 2012; Cook et al., 2013; Heneberg \& Bogusch, 2014) and production of copious pollen and nectar (Percival, 1955; Szabo, 1984). The vegetative parts of flowers are used by species that complete their development inside the receptacle and remain until seed maturation (Honek et al., 2005). In contrast, ligulate florets attract few herbivores (Breadmore \& Kirk, 1998; Bienkowski, 2010) except slugs (Honek \& Martinkova, 2014). Phytophagous species are followed by their predators and parasitoids (Hofsten, 1954; Honek \& Martinkova, 2005). Specialist seed predators only visit inflorescences at the stage of seed dispersal (Honek et al., 2013).

The communities populating dandelion flowers are rich and have attracted much interest (e.g. Hofsten, 1954; Judd, 1971; Jervis et al., 1993; Torres \& Galetto, 2002; Torres \& Galetto, 2011; Larson et al., 2014). In central Europe the communities present at seed maturation (Honek \& Martinkova, 2005, Honek et al., 2005) and dispersal (Honek et al., 2013) are also documented. Many insects visit the flowers despite their ephemerality. In this study, we recorded the arthropod communities associated with dandelion flowers at grassland sites where dandelions were abundant and discuss the ultimate (e.g. host plant taxonomic affiliation and local fauna of insect visitors) and proximate causes (pollen presence and microclimate of the flower) that determine flower community composition.

\section{MATERIALS AND METHODS}

\section{Study sites}

The observations were made in the grounds of the Crop Research Institute at Prague - Ruzyně, at 5 sites situated within a $750 \times 330 \mathrm{~m}$ area centred at $50^{\circ} 05^{\prime} 10^{\prime \prime} \mathrm{N}, 14^{\circ} 18^{\prime} 08^{\prime \prime} \mathrm{E}$ and at an altitude of $340 \mathrm{~m}$. The area is a mosaic of experimental and production fields, orchards, ornamental gardens, lawns and buildings. The sites $2-5$ were grasslands with naturally established dandelion populations cut 1-3 times per year (Fig. 1). Site 1 was an abandoned pear orchard with a diverse herbaceous vegetation and partly shaded by trees. In addition, observations on the distribution of Meligethes spp., with respect to the presence of pollen in dandelion flowers, was made on 18 May 2013 at Chlumská $\left(49^{\circ} 28^{\prime} 12^{\prime \prime} \mathrm{N}, 13^{\circ} 13^{\prime} 11^{\prime \prime} \mathrm{E}, 570 \mathrm{~m}\right.$ altitude), in a meadow bordering a field of flowering oilseed rape.

\section{Taraxacum flowering}

At Site 1, the dandelions flowered in May-June, and at Sites $2-4$, they flowered throughout the vegetative season. The flowers opened during the daytime. The times of the opening and closing of flowers was recorded at Site 4, on sunny days in April-October, 2009-2011. This site was visited at 15 min intervals. During each visit whether the flowers were open or closed was recorded 


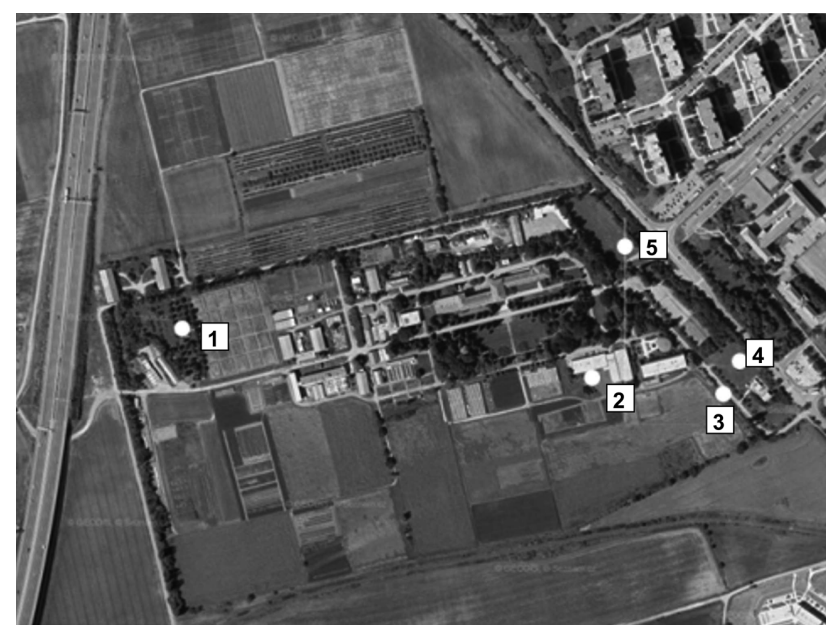

Fig. 1. Aerial picture of the Crop Research Institute, Prague Ruzyně showing the five sites where dandelion flowers were collected.

for 200 flowers (or less when the number of plants flowering was low). The visits began c. $30 \mathrm{~min}$ before the opening of the flowers in the morning. The percentage of open flowers was recorded at each successive visit and the time when $50 \%$ of the flowers were open estimated. The same counting procedure was repeated in the afternoon to establish the time at which the flowers closed.

To establish pollen presence, the examined flower was pressed against an adhesive surface (a piece of scotch tape), which resulted in pollen-producing flowers leaving a trace of pollen grains. The piece of scotch tape was then stuck to a sheet of paper. The pollen grains were permanently preserved below the scotch tape and the paper sheets with these samples were kept for later evaluation of pollen presence and quantity. The temperature of flowers was measured using a distant thermometer Raynger MX4 (Raytek Co., Santa Cruz, California, USA).

\section{Collecting arthropods}

During each sampling session, 30-100 flowers were collected with their fauna at each sampling site. The standard number was $3 \times 20$ flowers per site but numbers varied seasonally because of variation in the availability of flowers. The personal bias in sampling was minimal because the flowers were collected by a single person (AH). The sampling was conducted on sunny and calm days, between 09:00 and 12:00 h. Every attempt was made to avoid casting a shadow on the flowers or disturbing their fauna, by quickly approaching and plucking the randomly-selected flowers. With some experience, it was possible to collect all slow moving species and a representative number of strong-flying large species of Hymenoptera, Diptera and Lepidoptera using this method. Strong-flying representatives of these orders were also recorded without catching; however, if necessary for identification, they were caught using an entomology net. The sampling sessions were repeated at 5-7 d intervals, at sites 4 and 5. If flowers were rare or the sites were mowed, the sampling was extended to sites 2 and 3 .

The samples of flowers were taken to the laboratory and cooled to $5^{\circ} \mathrm{C}$. After exposure to room temperature, the immobilised arthropods that slowly left the plant material, were sampled using an aspirator, killed and mounted dry (large Coleoptera, Diptera, Heteroptera, Hymenoptera, and Lepidoptera) or preserved in $90 \%$ alcohol. The numbers of Thysanoptera were estimated in terms of tens and representative samples of c. 50 individuals were preserved for identification.
Factors influencing the distribution of Byturus ochraceus (Scriba) were studied at site 1 where some flowers were shaded by tree crowns. The observations were made on May 9, 2013, (between 09:30 and 11:30 h) on 351 dandelion flowers. Each flower was classified according to three criteria: presence/absence of pollen, shade/insolation and presence/absence of $B$. ochraceus. The temperature of 368 flowers was measured on May 12, 2013, and presence/absence of $B$. ochraceus in each flower recorded. The distribution of thrips was studied at Site 5, on June 20, 2013 (between 10:50 and 11:10 h). Each of 127 flowers was placed separately in a plastic bag. The numbers of thrips were then established in the laboratory as described above. Pollen presence and temperature were measured on another 50 flowers between 11:10 and 11:40. Meligethes spp. presence in particular flowers was established at Chlumská, on May 18, 2013 (between 11:20-12:00 h) when dandelion flowers were abundant and exposed to sunshine. Presence/absence of pollen and Meligethes spp. was recorded for 149 flowers.

To establish the difference between the fauna of flowers open during the daytime and those closed overnight, samples were collected at Site 2 on 14 June 2011 (open flowers collected at 10:00 h; closed flowers at 18:00 h), 8 August 2011 (12:00; 18:00), 10 August 2011 (11:00; 17:30) and 18 August 2011 (10:00; 18:30). Before the morning session, c. 60 flowers were marked by wooden labels. Half of these randomly-selected flowers were sampled in the morning session when open and the other half in the afternoon when closed.

\section{Data elaboration}

The arthropods collected in 2011-2012 were determined to species or genera by the authors and specialists listed in the Acknowledgements. All species names with their authorities are listed in Table 1.

To reveal seasonal trends in abundance of the insect orders (Coleoptera, Diptera, Heteroptera, Hymenoptera and other orders pooled), the samples collected in 2010-2012 were grouped in half-monthly intervals starting from April 1, and the percentage of particular groups in the total insect sample was calculated for each interval.

To determine the seasonal dynamics, the 2010-2012 data for each of the 5 most abundant species were recalculated. In each year, the maximum abundance was set to 1 and the other data expressed as a percentage of the maximum. Dates of sampling in each year were expressed as Julian days (days from January 1) and projected on a common abscissa. To reveal the seasonal trends in abundance of selected species the running means were calculated using values of abundance on 4 successive Julian days arranged on a common abscissa. This procedure smoothed small annual variation in species population dynamics and revealed general trends in species dynamics.

The characteristics of the fauna of particular insect orders were described using common indices. One of these, the Shannon-Wiener index of diversity $\left(H^{\prime}\right)$, is calculated as $H^{\prime}=-\Sigma\left(p_{i} * \log p_{i}\right)$, where $p_{i}$ is the proportion of the total number of individuals captured at a site composed of species $\mathrm{i}$. The Simpson index of dominance (c) is calculated as $c=\sum\left(n_{i} / N\right)^{2}$, where $n_{i}$ is number of individuals of a particular species and $\mathrm{N}$ is total number of individuals in the sample. The Margalef index of species richness (d) is calculated as $\mathrm{d}=(\mathrm{S}-1) / \log \mathrm{N}$, where $\mathrm{S}$ is the number of species in the sample and $\mathrm{N}$ the total number of individuals in the sample. Similarity between communities was calculated using the Sørensen index of similarity $(\mathrm{S})$, which indicates the identity of taxa present in compared samples and is calculated as $\mathrm{S}=2 \mathrm{C} /(\mathrm{A}+\mathrm{B})$, where $\mathrm{A}$ is the number of species in sample a (particular stage of 
Table 1. Species of arthropods collected from dandelion flowers. $\mathrm{N}$ represents the number of individuals collected in 2011-2012, and $\mathrm{N}=0$ indicates this species was only collected before 2011

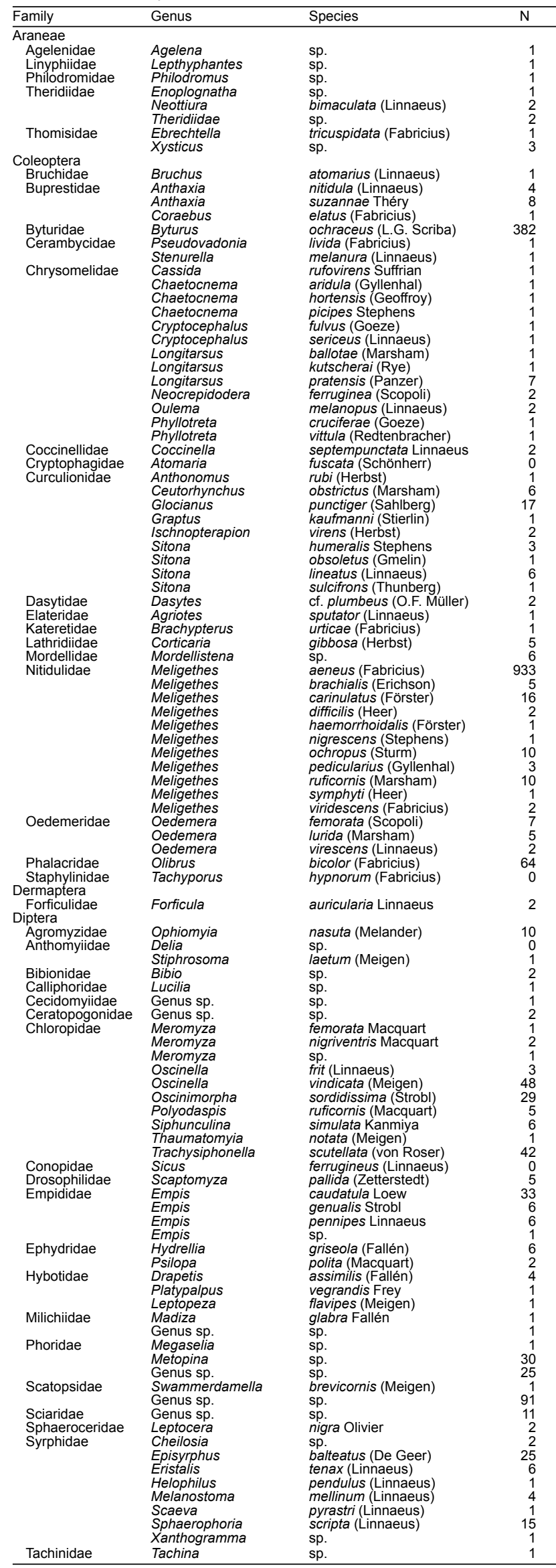

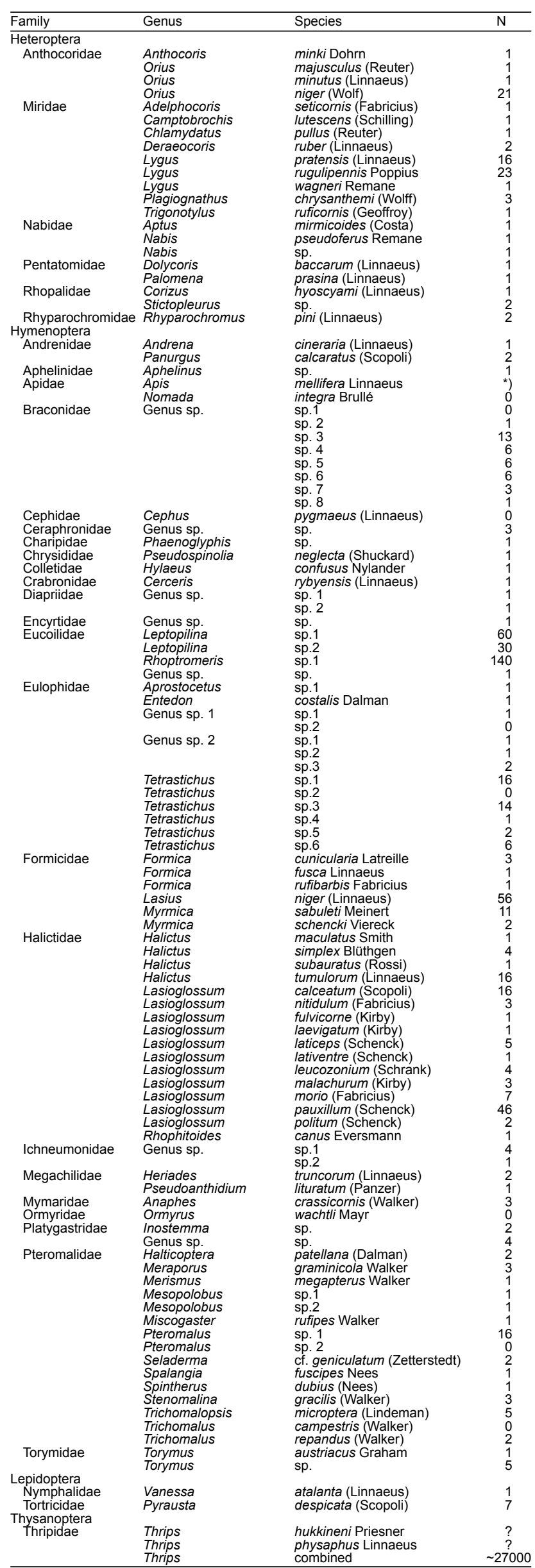




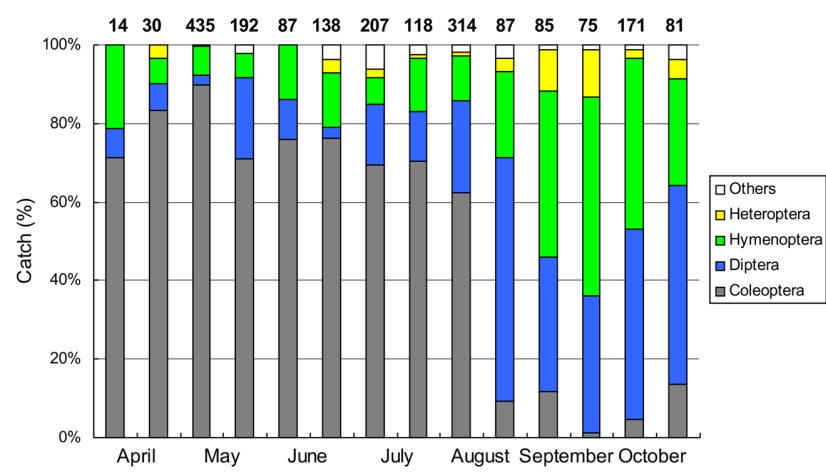

Fig. 2. The percentages of the different dominant insect orders (Thysanoptera not included) in the pooled samples collected over the period 2010-2012 presented for half monthly periods from April 1 to October 31 . Figures above bars indicate sample sizes (including all orders).

flower development), $B$ is the number of species in sample $b$, and $\mathrm{C}$ is number of species common to both samples $\mathrm{a}$ and $\mathrm{b}$.

The data on presence/absence of two species of Coleoptera in flowers were tested using $\mathrm{Chi}^{2}$ tests. The data on B. ochraceus was first tested with respect to presence/absence of pollen, then with respect to shading/insolation of flowers using only data for pollen bearing flowers. The presence of Meligethes spp. was tested with respect to presence/absence of pollen. Relationship between presence/absence of $B$. ochraceus and flower temperature was studied using a logistic regression within the Generalized Linear Model with a binomial error structure (GLM-b). The distribution of thrips in particular flowers was tested using a $\mathrm{Chi}^{2}$ goodness of fit and the coefficient of dispersion (Southwood \& Henderson, 2000). The coefficient of aggregation was estimated assuming a negative binomial distribution. Analyses were performed in the $\mathrm{R}$ environment (R Core Team, 2013).

\section{RESULTS}

\section{Arthropod community in dandelion flowers}

During the 3 years of this study (2010-2012) at Prague - Ruzyně, we identified c. 200 arthropod species (Table 1); however, some taxa could only be identified to genera or families. Numbers of individuals recorded per species are available for 2011-2012. The 12 species that were recorded only in 2010 or before the start of this study are also included. All species listed in Table 1 were identified as adults. In addition, larvae of weevils, Glocianus punctiger (Gyllenhal), were found boring into the receptacles (up to 5 larvae per flower).

Table 2. Characteristics of taxa associated with dandelion flowers. $\mathrm{Ns}$ is the number of species per taxon, $\mathrm{N}$ the number of individuals per taxon, $d$ the Margalef index of species richness, $c$ the Simpson index of dominance and $H^{\prime}$ the Shannon-Wiener index of diversity. Indices d, $\mathrm{c}$ and $\mathrm{H}^{\prime}$ were calculated only for taxa with $\mathrm{N}_{\mathrm{S}}>10$.

\begin{tabular}{lrrccc}
\hline & $\mathrm{N}_{\mathrm{s}}$ & $\mathrm{N}_{\mathrm{i}}$ & $\mathrm{d}$ & $\mathrm{c}$ & $\mathrm{H}^{\prime}$ \\
\hline Araneae & 8 & 12 & - & - & - \\
Coleoptera & 51 & 1536 & 15.69 & 0.4325 & 0.5929 \\
Dermaptera & 1 & 2 & & & \\
Diptera & 46 & 439 & 17.00 & 0.0873 & 1.2609 \\
Heteroptera & 21 & 83 & 11.37 & 0.1712 & 0.9788 \\
Hymenoptera & 86 & 575 & 30.38 & 0.0925 & 1.3782 \\
Lepidoptera & 2 & 8 & - & - & - \\
Thysanoptera & 2 & 27000 & - & - & - \\
\hline Total & 218 & $2655^{\mathrm{a}}$ & & & \\
\hline
\end{tabular}

a without Thysanoptera

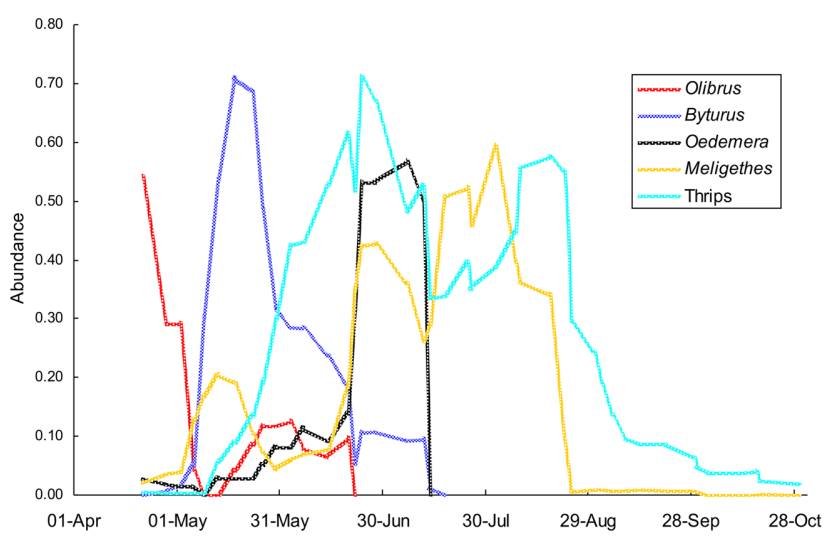

Fig. 3. Seasonal variation in the abundance of the dominant species in 2011. The abundances of each species was recalculated with the maximum daily abundance set at 1 and these values were used to calculate running means for periods of 4 successive days.

The order for which most species were recorded was Hymenoptera (Margalef index $\mathrm{d}=30.4$ ) followed by Diptera, Coleoptera and Heteroptera $(\mathrm{d}=17.0,15.7$ and 11.4, respectively), while only a few species were recorded for Lepidoptera and Thysanoptera (Table 2). Proportions of particular species in the total sample of an order were least diversified in Coleoptera (Simpson index $c=0.43$ ). This was due to the high prevalence of Meligethes aeneus (Fabricius) over the other species. In Heteroptera, Hymenoptera and Diptera, the species were represented in more similar proportions ( $\mathrm{c}=0.171,0.093$ and 0.087 , respectively). As a consequence, the taxon with highest diversity was Hymenoptera (Shannon-Wiener index $\mathrm{H}^{\prime}=1.378$ ), followed by Diptera $\left(\mathrm{H}^{\prime}=1.261\right)$, Heteroptera $\left(\mathrm{H}^{\prime}=0.979\right)$ and Coleoptera $\left(\mathrm{H}^{\prime}=0.593\right)$. The most numerous were Thysanoptera (Thrips physaphus Linnaeus and T. hukkineni Priesner in un-identified proportions), with a total number of c. 27,000 individuals in 2011-2012.

\section{Seasonal variation in the abundance of species}

There was a seasonal trend in the representation of taxa in the total sample of insects recorded at half-monthly intervals (Fig. 2). From the start of dandelion flowering in early April until mid-August, the insect community recorded in dandelion flowers was dominated by Coleoptera (representing $62-88 \%$ of the total insect sample). From late August, the dominant orders were Diptera (33-62\% of total insect community) and Hymenoptera (22-49\%). Heteroptera composed $0-12 \%$ of the total sample with a maximum in September.

The abundance of particular species followed a typical seasonal course (Fig. 3). Olibrus bicolor (Fabricius) was abundant in late April, Byturus ochraceus in May-June, Oedemera spp. in late June-early July. In contrast, the presence of Meligethes spp. (most were M. aeneus) and Thrips spp. extended throughout the vegetative season and had two peaks.

\section{Diurnal variation in the abundance of species}

For several hours each day dandelion flowers open their involucral bracts and expose the florets to insect visitors. The time of the opening of the flowers varied during the 

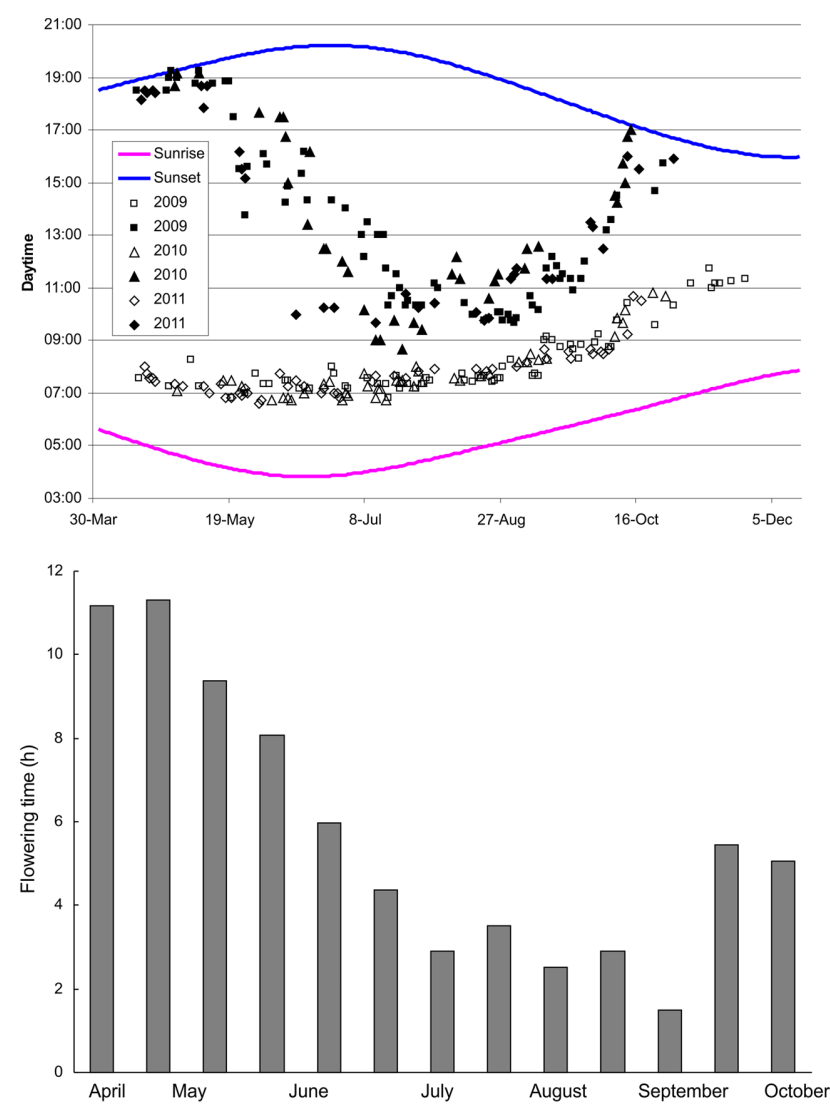

Fig. 4. Seasonal variation in the time of flowering. A - The opening (hollow symbols, $50 \%$ of flowers opened) and closing (black symbols) of dandelion flowers and time of sunrise and sunset. Each symbol represents one day of observation in 2009-2011. B - The mean length of the period for which the flowers remained open. This data was averaged for half-monthly periods starting April 15.

season and was always shorter than the light phase of the day (Fig. 4A). In the morning, the bracts opened 3-4 h after sunrise. In spring (April-May), they closed shortly before sunset (resulting in the flowers being open for 9-11 h). Later in the season, the bracts closed earlier, between 10:00 and 12:00 $\mathrm{h}$ in July-September, with flowers open for only $2-4 \mathrm{~h}$. Therefore, the length of the period for which dandelion flowers remained open for visitors varied greatly throughout the season (Fig. 4B).

The sampling of open flowers in the morning and closed flowers in late afternoon revealed large changes in the presence of species (Table 3). Most species, including Diptera, Hymenoptera, Heteroptera, Lepidoptera and many species of Coleoptera, were caught only in open flowers. The species collected in closed flowers were chiefly Meligethes and Thrips spp., which most likely remained in closed capitula overnight.

\section{Factors determining the abundance of particular species}

The numbers of insects present in particular flowers at a particular site varied substantially. We investigated pollen presence and flower temperature as factors that may influence the presence of the dominant species. The presence of $B$. ochraceus in a flower was influenced by both factors. These beetles were recorded most frequently (Table 4) in
Table 3. The species present in open and closed dandelion flowers. Thirty open flowers were sampled in each morning session and 30 closed flowers in each afternoon session. $\mathrm{N}$ is the number of individuals in the total sample of 120 open and 120 closed flowers sampled on 14 June, 8 August, 10 August and 18 August 2011.

\begin{tabular}{|c|c|c|}
\hline & Open $(\mathrm{N})$ & Closed (N) \\
\hline \multicolumn{3}{|l|}{ Coleoptera } \\
\hline Brachypterus urticae & 1 & \\
\hline Ceutorhynchus obstrictus & & 1 \\
\hline Longitarsus sp. & 1 & \\
\hline Meligethes aeneus & 64 & 119 \\
\hline Meligethes ochropus & & 1 \\
\hline Sitona lineatus & 1 & 2 \\
\hline \multicolumn{3}{|l|}{ Diptera } \\
\hline Empis genualis & 6 & \\
\hline Episyrphus balteatus & 6 & \\
\hline Lucilia sp. & 1 & \\
\hline Oscinimorpha sordidissima & 6 & \\
\hline Scatopsidae spp. & 21 & \\
\hline Sciaridae spp. & 2 & \\
\hline Siphunculina simulata & 1 & \\
\hline Stiphrosoma laetum & 3 & \\
\hline Swamerdamella brevicornis & 3 & \\
\hline Trachysiphonella scutellata & 44 & \\
\hline \multicolumn{3}{|l|}{ Heteroptera } \\
\hline Lygus pratensis & 3 & \\
\hline Palomena prasina & 1 & \\
\hline \multicolumn{3}{|l|}{ Hymenoptera } \\
\hline Aphelinus sp.1 & 1 & \\
\hline Halictus tumulorum & 4 & \\
\hline Lasioglossum lativentre & 1 & \\
\hline Lasioglossum leucozonium & 1 & \\
\hline Lasioglossum pauxillum & 7 & \\
\hline Myrmica schencki & & 1 \\
\hline Platygastridae sp.1 & 2 & \\
\hline Rhoptromeris sp.1 & 6 & 1 \\
\hline Tetrastichus sp.1 & 2 & \\
\hline Tetrastichus sp.3 & 8 & \\
\hline \multicolumn{3}{|l|}{ Lepidoptera } \\
\hline Lycaenidae & 2 & \\
\hline \multicolumn{3}{|l|}{ Thysanoptera } \\
\hline Thrips sp. & 1500 & 1480 \\
\hline N species & 27 & 7 \\
\hline $\mathrm{N}$ individuals (total) & 1698 & 1605 \\
\hline $\mathrm{N}$ individuals (thrips omitted) & 198 & 125 \\
\hline Sørensen index (S) & & 0.235 \\
\hline
\end{tabular}

pollen-producing flowers and especially those that were shaded. On May 12, 2013 the 50\% probability for insects leaving flowers was recorded at $17.1^{\circ} \mathrm{C}$ (Fig. 5), which was higher than the mean air temperature $16.5 \pm 0.34^{\circ} \mathrm{C}$ (measured at a nearby meteorology station) between 09:00 and 11:00 h that day. The presence of Meligethes spp. (Table 5) was significantly associated with pollen-bearing flowers.

The distribution of thrips was established on June 20, 2013, at Site 5. At that time, the frequency of pollen producing flowers was low (24\%). All flowers were exposed to sunshine and differences in flower temperatures were minimal $\left(30.7 \pm 0.11^{\circ} \mathrm{C}\right)$. All flowers $(\mathrm{n}=127)$ were occupied by thrips whose numbers varied between 1-62 individuals per flower. The distribution of thrips was not random $\left(\mathrm{Chi}^{2}\right.$ $=1284, \mathrm{P}<0.0001$ ) but moderately aggregated (Fig. 6), as indicated by the coefficient of dispersion, $C D=8.6$. The coefficient of aggregation was $\theta=2.8$.

\section{DISCUSSION}

\section{The characteristics of flowers that determine their attractiveness for insects}

Most of the micro-species of the Taraxacum section Ruderalia in the Czech Republic are apomicts (Trávníček 


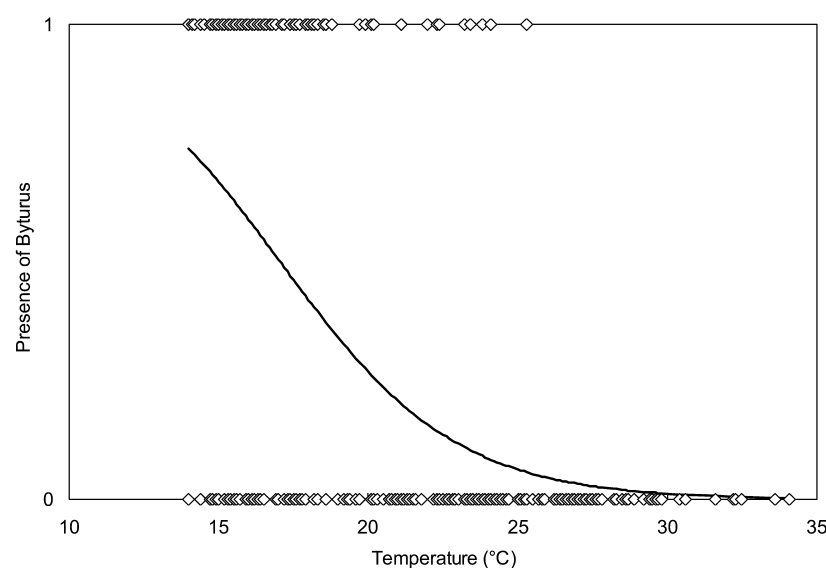

Fig. 5. Probability of Byturus ochraceus being present in flowers of Taraxacum section Ruderalia in relation to temperature. 0 on y axis indicates no beetles were present and 1 beetles present. The best fit to these results is the logistic function $y=1 /[1+\exp (-5.8+$ $0.34 \mathrm{x})]$ in which the inflex point $=17.06^{\circ} \mathrm{C}\left(\mathrm{GLM}-\mathrm{b}, X^{2}{ }_{1}=120.8\right.$, $P<0.0001)$.

et al., 2010). Nevertheless, the flowers produce nectar and (with a few exceptions) pollen and are visited by insects. The origin and biological significance of apomixis has been intensively studied (van Dijk \& Vijverberg, 2005), but the reasons why these flowers develop structures that are attractive and exploited by insects remain unexplained. This study provides basic data for future research on this topic.

The presence of insects in a dandelion flower results from a balance of the characteristics that attract and those that drive them away. Consider first the attractive properties of flowers of which the most important is providing food - nectar, pollen and vegetative tissues. Nectar is provided by all native micro-species but its accessibility to some visitors may be limited by long flower corollae (Dlussky et al., 2004). Its production in particular flowers varies with time and reaches a maximum on the second day of flowering (Szabo, 1984). Effect of the presence of pollen on the presence of insect visitors needs careful appraisal. The flowers of only $63 \%$ of the apomictic micro-species of section Ruderalia produce an abundance of pollen, 31\% some pollen and $6 \%$ no pollen (Trávníček et al., 2010). The presence of micro-species at a particular site and seasonal

Table 4. The observed and (expected) frequency of Byturus ochraceus in flowers collected at Prague - Ruzyně, site 1, May 9, 2013 The differences were tested using $\mathrm{Chi}^{2}$ test. The results were tested first using the data for all flowers for the effect of presence of pollen $\left(\mathrm{n}=351, \mathrm{Chi}^{2}=21.829, \mathrm{df}=1, \mathrm{P}<0.001\right)$, then using data for pollen bearing flowers for the effect of shading $\left(n=269, \mathrm{Chi}^{2}=\right.$ 121.490, df $=1, P<0.001$ ).

\begin{tabular}{|c|c|c|c|}
\hline \multirow{2}{*}{ Byturus } & \multicolumn{2}{|c|}{ Pollen } & \multirow{2}{*}{$\Sigma$} \\
\hline & present & absent & \\
\hline yes & 74 (58.2) & $2(17.8)$ & 76 \\
\hline no & $195(210.8)$ & $80(64.2)$ & 275 \\
\hline$\underline{\Sigma}$ & 269 & 82 & 351 \\
\hline \multirow{2}{*}{ Byturus } & \multicolumn{2}{|c|}{ Shade } & $\tau$ \\
\hline & present & absent & 2 \\
\hline yes & 59 (21.7) & $15(52.3)$ & 74 \\
\hline no & $20(57.3)$ & 175 (137.7) & 195 \\
\hline$\Sigma$ & 79 & 190 & 269 \\
\hline
\end{tabular}

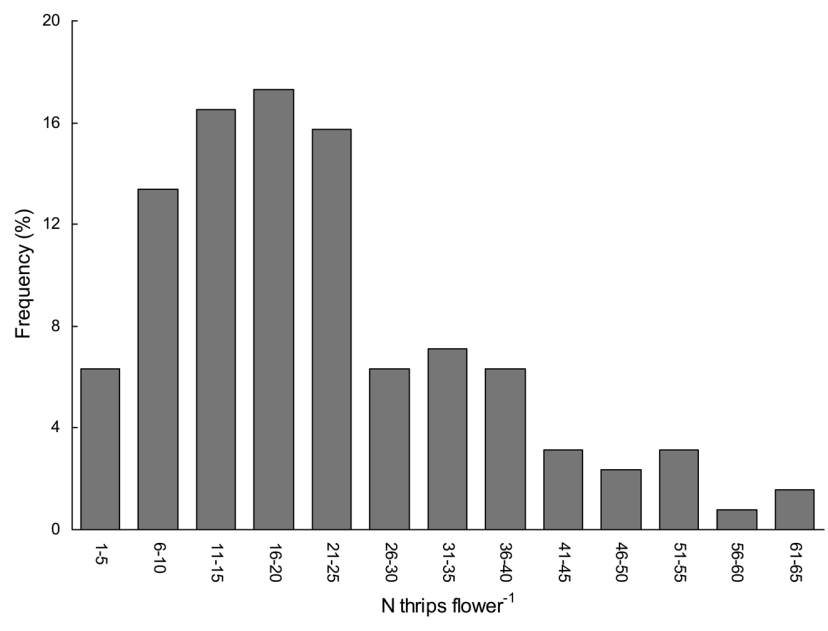

Fig. 6. The frequency distribution of thrips in dandelion flowers at Prague - Ruzyně, June 20, 2013.

variation in their flowering can result in a large seasonal variation in the availability of pollen bearing flowers. Thus at the localities investigated in early spring there was a $77-81 \%$ incidence of flowers bearing pollen (Tables 4 and 5), but later in the season, the percentage of "pollen rich" flowers at Praha-Ruzyně was low (see Results: Factors determining the abundance of particular species). Vegetative parts of the flower provide food for some visitors, particularly Coleoptera that consume soft receptacles (Honek \& Martinkova, 2005; Martinkova \& Honek, 2008).

Of the features of flowers attractive to insect visitors that are especially important is their yellow colour, which is generally attractive for insects, particularly so for the abundant visitors to dandelion flowers (Láska et al., 1986; Döring et al., 2012; Cook et al., 2013; Heneberg \& Bogusch, 2014). The effect of scent was investigated in $M$. aeneus, which can perceive the odour of host-plant flowers (Cook et al., 2002; Jonsson et al., 2007). For small insects, the dense tangle of florets in the flowers also provide shelter.

A constraint on insect presence in flowers is the short flowering time. The development of the dandelion capitulum in spring takes $24 \mathrm{~d} ; 9 \mathrm{~d}$ of stalk extension, $3 \mathrm{~d}$ of flowering, $10 \mathrm{~d}$ of seed maturation in closed capitula and $2 \mathrm{~d}$ of seed dispersal (Martinkova \& Honek, 2008). In summer, development may be shorter (Gray et al., 1973; Martinkova et al., 2011), but the relative duration of the stages remains the same. Therefore, flowering lasts for c. 13 percent of the development of a capitulum. This short period is further curtailed by the nocturnal closing of the flowers, which de-

Table 5. The observed and (expected) frequency of Meligethes sp. (largely $M$. aeneus) in flowers collected at Chlumská, May 18, 2013. The differences were tested using $\mathrm{Chi}^{2}$ test. The results were tested for the effect of presence of pollen $\left(n=149, \mathrm{Chi}^{2}=8.300, \mathrm{df}\right.$ $=1, P=0.004$ ).

\begin{tabular}{lccc}
\hline \multirow{2}{*}{ Meligethes } & \multicolumn{2}{c}{ Pollen } & $\Sigma$ \\
\cline { 2 - 3 } & present & absent & \\
\hline yes & $54(46.7)$ & $4(11.3)$ & 58 \\
no & $66(73.3)$ & $25(17.7)$ & 91 \\
$\Sigma$ & 120 & 29 & 149 \\
\hline
\end{tabular}


creases the total time a flower is displayed to insect visitors to $6-30 \mathrm{~h}(8-42 \%$ of the duration of the flowering phase). This time constraint is most likely overcome by the timing of the daily activities of insect visitors, which, as in other plants (Figueroa-Castro \& Cano-Santana, 2004), is most likely synchronised with flowering time.

\section{The characteristics of the fauna associated with flowers}

Several studies report fewer insects visiting dandelion flowers than recorded in the present study. This is not surprising as some of the studies were done in areas only recently invaded by dandelion, where floral visitors may be limited to polyphagous species (Judd, 1971; Larson et al., 2014). In areas where dandelion is native, the most important reason for the difference is the extraordinary attention paid to large pollinators (Memmott, 1999). In addition, only individuals that were on the surface of the flowers were recorded (Torretta \& Poggio, 2013) and this results in lower numbers of records for Asteraceae in general (Tooker \& Hanks, 2000; Cerana, 2004; Graham et al., 2012; Torretta \& Poggio, 2013) because it does not include the many species that hide in the tangle of disc florets and are not present on surface of the flowers. This negatively affects the counts of small species of Hymenoptera, Diptera and Coleoptera. In contrast, in the present study, numbers of large Hymenoptera and Lepidoptera may be reduced compared with those recorded by e.g. Larson et al. (2014), due to the shortness of the sampling sessions. Here we will avoid a lengthy discussion of pollination (Kevan \& Baker, 1983; Wackers et al., 2007). All dandelion microspecies included in this study were apomictic; therefore, pollination is not important for their life cycle. This specific fact deserves to be accentuated because pollination is an important facet of plant-insect relationships, and one of the factors driving their co-evolution (Schiestl \& Johnson, 2013; Wardhaugh, 2015).

There are several reasons for the presence of insects in and on dandelion flowers as the fauna includes members of several trophic guilds. Phytophagous species that consume plant tissues include a few species of which the eggs and larvae complete their development in dandelion flowers. For example, larvae of $G$. punctiger start consuming the receptacle before flowering and continue eating the maturing seeds (Honek \& Martinkova, 2005, Martinkova \& Honek, 2008). Vegetative flower tissues are also a source of food for chrysomelid beetles (Bienkowski, 2010). Ubiquitous and polyphagous species of Heteroptera (14 species recorded in this study) may also feed on the vegetative tissues of dandelion flowers exploiting particularly the latex, potentially for sequestration (Rhopalidae).

Some of the species were pollen feeders. Pollen is an important source of food for some Diptera, such as Anthomyiidae, Empidae, Scatopsidae and Syrphidae, which are known pollen feeders (Larson et al., 2001). Families known as "anthophilous" or "pollinators" (Agromyzidae, Calliphoridae, Conopidae, Drosophilidae, Ephydridae, Milichiidae and Sphaeroceridae) might also be pollinivorous (Larson et al., 2001). In Hymenoptera pollinivory may be rare, most likely limited to parasitoid species of Braconidae, Encyrtidae, Eulophidae, Pteromalidae and Platygasteridae (Hassan, 1967; Jervis et al., 1993; Jervis, 1998), which were also recorded in this study. In contrast, Hymenoptera are important collectors of pollen. Female bees, belonging to the Apidae, Halictidae and Megachilidae, recorded in this study collect pollen to feed their offspring. Coleoptera, Byturidae (Miller, 1956), Oedemeridae (Sivilov et al., 2011) and Dasytidae (Mawdsley, 2003) are important pollen feeders. Important pollen consumers were M. aeneus (representing 95\% of Meligethes spp. complex) and 10 other Meligethes species. In a similar assemblage of Meligethes species recorded on flowers of oilseed rape (Brassica napus Linnaeus), M. aeneus accounts for $71-97 \%$ of samples of these beetles collected at different localities in the Czech Republic (Toth et al., 2013). Among the Heteroptera, some Orius species are facultative pollinivores, particularly in early spring, and can even complete their development on a pollen diet (Lattin, 2000; Tan et al., 2011). Thrips occupy flowers when they produce pollen (Kirk, 1984, 1987), which they consume. Furthermore, the extent to which ants visit flowers and consume pollen and their role in pollination is far from clear (Kevan \& Baker, 1983; Wardhaugh, 2015).

Another important source of food for floral visitors is nectar (Kevan \& Baker, 1983). For Diptera, nectar is most likely less important than pollen, but it is consumed by species of Anthomyiidae, Chloropidae, Phoridae and Syrphidae (Larson et al., 2001). Some parasitoid groups of Hymenoptera included in this study (Braconidae, Chrysididae and Ichneumonidae) have mouthparts adapted for consuming nectar (Jervis, 1998). The bee species found in this study consume nectar. The coleopteran families $\mathrm{Bu}-$ prestidae (Barker, 2005), Dasytidae (Mawdsley, 2003) and Cerambycidae (O’Neill et al., 2008) are also nectar feeders.

Predators are an important component of flower communities. All Araneae found on flowers were ubiquitous species living on herbaceous vegetation with a broad spectrum of prey. Abundant Orius spp. (Heteroptera, Anthocoridae) among which the most abundant is $O$. niger (Wolff) feed mainly on thrips (Lattin, 2000; Bosco et al., 2008). Species collected in low numbers (1-2 individuals over the 2 year period) are probably accidental visitors and do not have a functional relationship with dandelion flowers. Dandelion flowers are conspicuous, large, unprotected, provide shelter and have a convenient microclimate that is attractive to accidental visitors.

\section{Ultimate and proximate determinants of community composition}

The specific characteristics of dandelion flowers determine the dandelion community (Torres \& Galetto, 2002). This is apparent from a parallel study of the faunas of the flowers of different species at Site 1 recorded in June 2012 (Martinkova et al., 2015). In that study 49 species of insects (920 individuals) were recorded visiting the flowers of dandelion and 10 other species of herbaceous plants belonging to 7 families. The similarity in species visiting 
the flowers of dandelion and other herbaceous plants was low (mean Sørensen index $S=0.250 \pm 0.050$ ). The highest similarity $(\mathrm{S}=0.563)$ was between those recorded visiting the flowers of Taraxacum (19 species, 111 individuals collected) and Crepis biennis Linnaeus (14 spp., 286 ind.), most likely due to the close taxonomic relationship of these host plants and the similar sizes and colours of the flowers (Martinkova et al., 2015). These insect communities are assembled based on particular characteristics of the flowers of the different species.

Only species that complete their development in the capitulum and reside there throughout their development ( $G$. punctiger, $O$. bicolor, thrips) were present as larvae. Other species were present as adults, and, in most cases, capable of flight. Diptera and Hymenoptera are typical visitors of the flowers. Coleoptera and Heteroptera are present also at other stages of development of the capitulum, with few species both visiting the flowers and present at later stages of development (Honek et al., 2005, 2013).

The proximate causes of community composition are the behavioural patterns that result in an insect visiting a flower. For insect visitors flight is a precondition and the typical means of moving between dandelion flowers and therefore these visitors are adults. Some species may be poor fliers due to their small size. Their presence is facilitated by the great density of flowers, which at peak flowering may reach several tens $\mathrm{m}^{-2}$. Mobile large spiders may easily reach flowers by walking, nevertheless their numbers in dandelion flowers were low.

Beside presence of pollen, flower temperature is an important factor determining insect activity on flowers (Orueta, 2002; Kleckova et al., 2014). Temperature was essential for $B$. ochraceus as they were more frequently recorded in the shaded cooler flowers than in warm flowers in full sun. In contrast, B. tomentosus (DeGeer) (Willmer et al., 1996), unlike B. ochraceus, visits flowers exposed to the sun's rays to increase their body temperature above the threshold required for flight.

\section{CONCLUSIONS}

The fauna associated with dandelion (Taraxacum section Ruderalia) flowers is rich despite features that might predict the reverse. Although they do not need to attract pollinators, the apomictic micro-species of dandelion produce flowers with food rewards sufficiently strong to attract insects even though the individual flowers are only open for few hours each day. Therefore, the fauna mainly consists of adult insects that only visit the flowers while they are open during the day. The insect community associated with dandelion flowers differs from that of other herbaceous plants simultaneously flowering at the same site. Except for the few species that complete their development in the flowers, the insect community changes as the flowers age. Floral visitors are attracted by floral rewards and the flower microclimate. The benefits to dandelion of producing flowers with rich rewards for insects should be further investigated.
ACKNOWLEDGEMENTS. We thank P. Werner for identifying the ants, J. Kohoutová and H. Uhlírová for their excellent technical assistance, and American Journal Experts for improving the English and editing the MS. AH, ZM and JS were supported by project \# RO0415 of the Ministry of Agriculture of the Czech Republic; JH, JJ, VK and JŠ by the Ministry of Culture of the Czech Republic (\#DKRVO 2015/13, National Museum, 0002327201); PJ by the Institutional Research Support grant \#SVV 260 087/2014; PŠ by the financial support of Czech Science foundation (P505/11/1459); and MB was supported by grant \#S of the Ministry of Education, Sports and Youth.

\section{REFERENCES}

BARKER S. 2005: Nine new species of Castiarina Gory \& Laporte, 1838 (Coleoptera: Buprestidae). — Zootaxa 1062: 57-68.

Bienkowski A.O. 2010: Anthophagy in leaf-beetles (Coleoptera, Chrysomelidae). - Zool. Zh. 89: 588-597.

Bosco L., Giacometto E. \& Tavella L. 2008: Colonisation and predation of thrips (Thysanoptera: Thripidae) by Orius spp. (Heteroptera: Anthocoridae) in sweet pepper greenhouses in Northern Italy. - Biol. Contr. 44: 331-340.

BREADMORE K.N. \& KIRK W.D.J. 1998: Factors affecting floral herbivory in a limestone grassland. - Acta Oecol. 19: 501506.

CERANA M.M. 2004: Flower morphology and pollination in Mikania (Asteraceae). - Flora 199: 168-177.

Cook S.M., Bartlet E., Murray D.A. \& Williams I.H. 2002: The role of pollen odour in the attraction of pollen beetles to oilseed rape flowers. - Entomol. Exp. Appl. 104: 43-50.

COOK S.M., Skellern M.P., Döring T.F. \& Pickett J.A. 2013: Red oilseed rape? The potential for manipulation of petal colour in control strategies for the pollen beetle (Meligethes aeneus). Arthr.-Plant Interact. 7: 249-258.

Dlussky G.M., Glazunova K.P. \& Lavrova N.V. 2004: The flower and blossom morphology of Asteraceae correlates with composition of their pollinators. - Zh. Obshch. Biol. 65: 490-499.

Döring T.F., Skellern M., WatTs N. \& CoOK S.M. 2012: Colour choice behaviour in the pollen beetle Meligethes aeneus (Coleoptera: Nitidulidae). - Physiol. Entomol. 37: 360-368.

Figueroa-CAStro D.M. \& CANo-Santana Z. 2004: Floral visitor guilds of five allochronic flowering Asteraceous species in a xeric community in central Mexico. - Environ. Entomol. 33: 297-309.

Girard M., Chagnon M. \& Fournier V. 2012: Pollen diversity collected by honey bees in the vicinity of Vaccinium spp. crops and its importance for colony development. - Botany $\mathbf{9 0}$ : $545-555$.

Graham E.E., ToOKer J.F. \& Hanks L.M. 2012: Floral host plants of adult beetles in central Illinois: an historical perspective. Ann. Entomol. Soc. Am. 105: 287-297.

Gray E., McGehee E.M. \& Carlisle D.F. 1973: Seasonal variation in flowering of common dandelion. - Weed Sci. 21: 230-232.

HASSAN E. 1967: Untersuchungen über die Bedeutung der Krautund Strauchschicht als Nahrungsquelle für Imagines entomophager Hymenopteren. - Z. Angew. Entomol. 60: 238-265.

Heneberg P. \& Bogusch P. 2014: To enrich or not to enrich? Are there any benefits of using multiple colors of pan traps when sampling aculeate Hymenoptera? - J. Insect Conserv. 18: 1123-1136.

Hofsten C.G. von 1954: Studies on the Genus Taraxacum with Special Reference to the Group Vulgaria DT in Scandinavia. LTs, Stockholm, 431 pp. [in Swedish]. 
Honek A. \& Martinkova Z. 2005: Pre-dispersal predation of Taraxacum officinale (dandelion) seed. - J. Ecol. 93: 335344.

Honek A. \& Martinkova Z. 2014: Floral herbivory of an invasive slug on a native weed. - Plant Prot. Sci. 50: 151-156.

Honek A., Martinkova Z., Hurka K. \& Stys P. 2005: Insect community in maturing capitula of dandelion (Taraxacum officinale). - Biologia 60: 559-565.

Honek A., Stys P. \& Martinkova Z. 2013: Arthropod community of dandelion (Taraxacum officinale) capitula during seed dispersal. - Biologia 68: 330-336.

Jenniskens M.J.P.J., Wetzels P. \& Sterk A.A. 1984: Aspects of the flowering ecology of taxa of Taraxacum section Taraxacum. In Jenniskens M.J.P.J. (ed.): Aspects of the Biosystematics of Taraxacum section Taraxacum. Academic Press, Amsterdam, pp. 23-65.

JERVIS M. 1998: Functional and evolutionary aspects of mouthpart structure in parasitoid wasps. - Biol. J. Linn. Soc. 63 461-493.

Jervis M.A., Kidd N.A.C., Fitton M.G., Huddleston T. \& Dawah H.A. 1993: Flower-visiting by hymenopteran parasitoids. $-J$. Nat. Hist. 27: 67-105.

Jonsson M., RosDahl K. \& ANDERson P. 2007: Responses to olfactory and visual cues by over-wintered and summer generations of the pollen beetle, Meligethes aeneus. - Physiol. Entomol. 32: 188-193.

JudD W.W. 1971: Studies on the Byron Bog in southwestern Ontario. XLV. Insects associated with flowering dandelion, Taraxacum officinale Weber. - Proc. Entomol. Soc. Ont. 101: 59-62.

Kevan P.G. \& BaKer H.G. 1983: Insects as flower visitors and pollinators. - Annu. Rev. Entomol. 28: 407-453.

KIRK W.D.J. 1984: Pollen-feeding in thrips (Insecta: Thysanoptera). - J. Zool. 204: 107-117.

KIRK W.D.J. 1987: How much pollen can thrips destroy? - Ecol. Entomol. 12: 31-40.

KIRSCHNER J. \& ŠTĚPÁNEK J. 1994: Clonality as a part of the evolution process in Taraxacum. - Folia Geobot. Phytotaxon. 29 265-275.

Kirschner J., ŠtěpÁnek J., Mes T.H.M., Den Niss J.C.M., OOsterveld P., Štorchová H. \& Kuperus P. 2003: Principal features of the cpDNA evolution in Taraxacum (Asteraceae, Lactuceae): a conflict with taxonomy. - Plant Syst. Evol. 239: 231-255.

Kleckova I., Konvicka M. \& KLecKa J. 2014: Thermoregulation and microhabitat use in mountain butterflies of the genus Erebia: Importance of fine-scale habitat heterogeneity. $-J$. Therm. Biol. 41: 50-58.

Larson B.M.H., Kevan P.G. \& Inouye D.W. 2001: Flies and flowers: taxonomic diversity of anthophiles and pollinators. Can. Entomol. 133: 439-465.

Larson J.M., Kesheimer A.J. \& Potter D.A. 2014: Pollinator assemblages on dandelions and white clover in urban and suburban lawns. - J. Insect Conserv. 18: 863-873.

LÁsKa P., Zelenková I. \& BIČ́́K V. 1986: Color attraction in species of the genera Delia (Diptera, Anthomyidae), Ceutorhynchus, Meligethes and Phyllotreta (Coleoptera, Curculionidae, Nitidulidae, Chrysomelidae). — Acta Entomol. Bohemoslov. 83: 418-424.

LatTIN J.D. 2000: Minute Pirate bugs (Anthocoridae). In Schaefer C.W. \& Panizzi A.R. (eds): Heteroptera of Economic Importance. CRC Press, Boca Raton, London, New York, Washington, pp. 607-637.

MartinKova Z. \& HoneK A. 2008: Contrast adaptation to time constraints on development of two pre-dispersal predators of dandelion (Taraxacum officinale) seed. - Biologia 63: 418426.

Martinkova Z., Honek A. \& LuKas J. 2011: Viability of Taraxacum officinale seeds after anthesis. - Weed Res. 51: 508-515.

Martinková Z., Skuhrovec J., Barták M., BezděK J., Bogusch P., Hadrava J., HáJek J., JanŠta P., JelíneK J., KubáŇ V. \& Štys P. 2015: Role of host plant in determining the insect community associated with the flowers of dicotyledoneous herbaceous plants. - Acta Soc. Zool. Bohem. 79: 95-104.

MAWDSLEY J.R. 2003: The importance of species of Dasytinae (Coleoptera: Melyridae) as pollinators in western North America. - Coleopts. Bull. 57: 154-160.

Меммотт J. 1999: The structure of a plant-pollinator food web. - Ecol. Lett. 2: 276-280.

Miller F. 1956: Agricultural Entomology. Czech Academy of Sciences, Prague, 1056 pp. [in Czech].

Nius J.C.M., Kirschner J., Štť́pÁNeK J. \& Hulst A. 1990: Distribution of diploid sexual plants of Taraxacum sect. Ruderalia in east-Central Europe, with special reference to Czechoslovakia. - Plant Syst. Evol. 170: 71-84.

O’Neill K.M., Fultz J.E. \& IVIE M.A. 2008: Distribution of adult Cerambycidae and Buprestidae (Coleoptera) in a subalpine forest under shelterwood management. - Coleopts. Bull. 62: 27-36.

ORUETA D. 2002: Thermal relationships between Calendula arvensis flowers and Usia aurata bombyliid flies. - Ecology 83: 3073-3085.

Percival M.S. 1955: The presentation of polen in certain angiosperms and its collection by Apis mellifera. - New Phytol. 54: 353-368.

R Core Team 2013: R: A Language and Environment for Statistical Computing. R Foundation for Statistical Computing, Vienna, URL http://www.R-project.org/

RichaRdS A.J. 1973: The origin of Taraxacum agamospecies. Bot. J. Linn. Soc. 66: 189-211.

Richards A.J. 1997: Plant Breeding Systems. 2nd ed. Chapman \& Hall, London, 529 pp.

SChIESTL F.P. \& Johnson S.D. 2013: Pollinator-mediated evolution of floral signals. - Trends Ecol. Evol. 28: 307-315.

Sivilov O., Atanassova J. \& Zlatkov B. 2011: Food plant spectrum of Oedemeridae species (Insecta, Coleoptera) based on pollen analysis (a preliminary study). - C. R. Acad. Bulg. Sci. 64: $225-230$.

Solbrig O.T. \& Simpson B.B. 1974: Components of regulation of a population of dandelions in Michigan. - J. Ecol. 62: 473-486.

Solbrig O.T. \& Simpson B.B. 1977: A garden experiment on competition between biotypes of the common dandelion (Taraxacum officinale). - J. Ecol. 65: 417-430.

Southwood T.R.E. \& Henderson P.A. 2000: Ecological Methods. Blackwell Science, Oxford, 575 pp.

ŠTĚPÁNEK J. \& KIRSCHNER J. 2012: A taxonomic revision of Taraxacum sect. Erythrosperma (Compositae: Lactuceae) in Corsica. - Feddes Repert. 123: 139-176.

Sterk A.A. \& Luteisn M.M. 1984: A study of the flowering phenology of Taraxacum microspecies in some biotopes in the Netherlands as observed during three successive years. - Acta Bot. Neerl. 33: 39-59.

SzABo T.I. 1984: Nectar secretion in dandelion. - J. Apic. Res. 23: 204-208.

Tan J.G., Paradise M.S., Levine S.L., Bachman P.M., Uffman J.P., JiAnG C.J. \& CARSON D.B. 2011: Development and survival of Orius insidiosus (Say) nymphs on encapsulated bee pollen-based diet in a Tier-I toxicity assay. - Environ. Entomol. 40: 1613-1621. 
ToOKer J.F. \& HANKS L.M. 2000: Flowering plant hosts of adult hymenopteran parasitoids of central Illinois. - Ann. Entomol. Soc. Am. 93: 580-588.

TORRES C. \& GALETTO L. 2002: Are nectar sugar composition and corolla tube length related to the diversity of insects that visit Asteraceae flowers? - Plant Biol. 4: 360-366.

Torres C. \& Galetto L. 2011: Flowering phenology of co-occurring Asteraceae: a matter of climate, ecological interactions, plant attributes or of evolutionary relationships among species? -Org. Divers. Evol. 11: 9-19.

Torretta J.P. \& Poggio S.L. 2013: Species diversity of entomophilous plants and flower-visiting insects is sustained in the field margins of sunflower crops. - J. Nat. Hist. 47: 139-165.

Toth P., Hrudova E., Sapakova E., Zavadska E. \& Seidenglanz M. 2013: Species of the genus Meligethes occurring in oilseed crop fields in the Czech Republic. - Plant Prot. Sci. 49: $177-186$.

TrÁVNíČEK B., KirSCHNER J., ŠTĚPÁNEK J. \& VAŠUt R.J. 2010 Taraxacum Wiggers - dandelion. In Chrtek J., Kaplan Z. \& Štěpánková J. (eds): Flora of the Czech Republic . Vol. 8. Academia, Prague, pp. 23-269 [in Czech].
VAN DiJK P.J. \& ViJverberg K. 2005: The significance of apomixis in the evolution of the angiosperms: a reappraisal. In Bakker F.T., Chatrou L.W., Gravendeel B. \& Pelser P.B. (eds): Plant Species-Level Systematics: New Perspectives on Pattern \& Process. ARG Gantner KG, C/O Koeltz Scientific Books, Koenigstein, pp. 101-116.

WACKeRS F.L., RomeIS J. \& van RIJN P. 2007: Nectar and pollen feeding by insect herbivores and implications for multitrophic interactions. - Annu. Rev. Entomol. 52: 301-323.

WARDHAUGH C.W. 2015: How many species of arthropods visit flowers? - Arthr.-Plant Interact. 9: 547-565.

Willmer P.G., Hughes J.P., Woodford J.A.T. \& Gordon S.C. 1996: The effects of crop microclimate and associated physiological constraints on the seasonal and diurnal distribution patterns of raspberry beetle (Byturus tomentosus) on the host plant Rubus idaeus. - Ecol. Entomol. 21: 87-97.

Received October 12, 2015; revised and accepted January 14, 2016 Published online February 5, 2016 